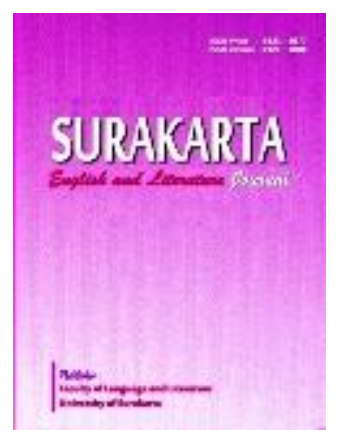

SURAKARTA ENGLISH AND LITERATURE JOURNAL

Vol 4 No 1 February 2021

Publisher Language and Literature Faculty, University of Surakarta

ISSN Print: 2621-9077 ISSN Online: 2621-9085

\title{
THE USE OF FLASHCARD IN TEACHING ENGLISH VOCABULARIES BY YOUNG MOTHERS
}

\author{
Nurnaningsih
}

English Department, University of Veteran Bangun Nusantara Sukoharjo, nurnananinx@gmail.com

\begin{abstract}
This study aims to determine how to apply flashcards in teaching English vocabulary by young mothers in the Dawis PKK Desa Dua Belasan RT I RW III Jombor Kec. Bendosari Kab Sukoharjo. The problems in this study were examined by qualitative descriptive research because the results of the approach were explained by using words. This research was conducted in the village of Dua belasan Jombor Sukoharjo. Meanwhile, data collection techniques are observation and documentation. The use of flashcards to teach English can be done in three ways. Flashcards in the standard way, namely quickly changing flashcards in front of the children, then flashcards were combined with songs and lastly flashcards were combined with hide and seek games. There are two advantages of a flashcard, it is like a game and it can be combined by singing a song. Apart from that, there are two weaknesses of using the flashcard. Teachers must be creative and must find ways to integrate other media on an ongoing basis. Then, Children did not feel bored in learning English using flashcards.
\end{abstract}

Keywords: Flashcards, English, Vocabularies

\section{INTRODUCTION}

Sukoharjo Regency is one of the largest districts in the Surakarta Residency. The district has subordinate areas scattered around the Surakarta Municipality. One of them is Jombor subdistrict where Duabelasan Village is located. The village has 40 family heads with $75 \%$ of the total number of families in the village of Duabelasan who are young couples of productive age, and of the total number of heads of families in the village of Duabelasan, $60 \%$ are from the middle to lower economic class. Meanwhile, $45 \%$ of the young mothers in the village are housewives with high school education. The young mothers need an easy teaching media to use in teaching their children.

The obstacle for these young mothers is when these activities have touched on activities related to their children's academic abilities. The reason is that the educational materials obtained by children with their parents' educational materials. In this case their mothers, have progressed very 
rapidly. Their children will miss the educational material especially English. English is a material they haven't gotten for a long time.

English is included in foreign language material that has been introduced since elementary school (Fridani, Lara; Dhieni, 2014), even for pre-schools (TK) which have entered the category of superior schools have started to include foreign languages as enrichment material.

The economic and educational factors of young mothers in Duabelasan Village make children in the village not really understand English lessons. The reason is that they only get English lessons when they are in school.

Simple and easy media that can be used in an effort to improve learning English at a low cost, one of which is by using Flashcards (Hidayat et al., 2012). Flashcards are cards specially made for the introduction of vocabulary in English (Rini et al., 2019) The card uses a picture that is easy for pre-school age children to remember. By attractive colors, these cards can make children easier to understand the meaning of vocabulary in a relatively fast time. This card is also very easy to use and to make yourself at home. The goal is that the housewives in Duabelasan Village can master basic English and can teach English to their children.

Actually, this flashcard is used to learn to read for young children, namely by making the child recognize the form of writing and memorizing the pairs of letters being observed. (Rahman \& Haryanto, 2014). The function of the image on the flashcard is to help students memorize. The reason for using pictures is to consider the way early childhood thinks. The thinking process of early childhood is still by describing, not analyzing (Papert, 1972). The explanation of the description is that everything is studied by imagining the object or in other words, early childhood thinks with the process of describing what is inside their head, while for adults or adolescents, the thinking process uses nalaisa, which is already knowing and understanding what is meant by cause and effect.

The image on the flashcard must have a color that attracts students' attention (Musyahidah et al., 2019). Attractive colors are colors that are easy to remember or easily captured and recognized by the early childhood, such as red and other basic colors. The base color has a thick or clear color contour, unlike the orange color, which is already a mixed color.

The reason young mothers use flashcards (reading learning tools for early childhood) is that they are easy to obtain by buying in stores or making your own (National Reading Panel, 2000). This self-made flashcard also has a positive effect on early childhood, namely to introduce and teach children's fine motor skills to be more honed. So that this flashcard has benefits in teaching reading as well as sharpening children's fine motor skills which are the initial capital or useful for writing and memorizing vocabulary.

Vocabularies themselves are one of the success factors for someone in learning language (Sitompul, 2013). The more vocabulary a person can master, the easier it will be for that person to master the language that is being studied. An example that can be used is someone who masters enough English vocabularies so that person will easily recognize and be able to read easily because the vocabulary of Indonesian as a mother tongue and English is very different so that the reading method is different. In English there is the word "book" in English. Indonesian can be read ok, but in English the word "book is read only a book.

Based on those previous researches, the researcher is interested in conducting a research on young mothers at the Dawis PKK Desa Dua Belasan Belasan RT I RW III Jombor Kec. Bendosari Kab Sukoharjo. in teaching English vocabulary using flashcards, and are expected the children to be interested to be interested in learning and like English. Based on the existing problems, the researcher formulated the problems: How does the usage of Flashcard to teach English vocabularies by young motherhood at Dawis PKK Desa Dua Belasan Belasan RT I RW III Jombor Kec. Bendosari Kab Sukoharjo.?

\section{Surakarta English and Literature Journal}




\section{METHODOLOGY}

Vol 4 No 1 February 2021

\section{Research methods}

The problem studied in this research is a research centered on natural events without any social and dynamic conjecture because what is being studied is a human being who coordinates and collaborates with other humans around him. This is as stated by (Miles \& Hubberman, 2014)about qualitative research. The conclusion that can be drawn from the explanation of Miles and Hubberman is that this research is a qualitative research because the real conditions that exist in the interaction of young mothers and children in the PKK environment of the village of Duabelasan Jombor Sukoharjo are examined.

\section{Research sites}

Based on (Khan, 2014) said, this research was conducted in the Dawis PKK Desa Dua Belasan Belasan RT I RW III Jombor Kec. Bendosari Kab Sukoharjo.

\section{Data source}

In this study the collected data consisted of primary data and secondary data (Sutton \& Austin, 2015).

1. Primary data, which is the main information in research, includes all qualitative data obtained through observation and documentation. In this case, the research data is a description of the use of flashcards for young mothers at the PKK community gathering in the village of Duabelasan Jombor Sukoharjo, the source of the data is the interaction between young mothers and the young mothers' children.

2. Secondary data, is data obtained through reference books in the form of notions and theories that have to do with the problem being studied.

\section{Data Collection Techniques}

The data collection procedures in this study included observation and documentation as expressed by (Davidavičienè, 2018).

\section{Observation}

Observation is the first step in conducting research, observations are made to find out in detail the location and conditions of the residence of young mothers in the PKK village of Duabelasan which will be examined both from the usual way of learning and the interaction between children and mothers in the learning process

2. Documentation

Documents are defined as a written record / stored image of something that has happened. Documentation is physical evidence in the form of photos taken when conducting research, in observing activities, and observing the learning process when PKK young mothers in Duabelasan Village teach English vocabulary to their children.

\section{Data Analysis Techniques}

(Flick, 2012), explained that data analysis is the steps to process research findings that have been transcribed through a data reduction process, namely the data is filtered and rearranged, presented, verified or made conclusions.

\section{Surakarta English and Literature Journal}




\section{The Validity of The Data}

In this study the validity of the data uses triangulation. (Bowen, 2009) identifies several types of triangulation, include:

1. Triangulation of data source

2. Investigator triangulation

3. Theory triangulation

4. Methodological triangulation.

Among those four triangulation types, one of them is applied in the study : there are theory triangulation. The researcher takes theory triangulation to examine the validity of the data.

\section{RESULTS AND DISCUSSION}

\section{Result}

Young mothers in the neighbourhood already know and understand the meaning of Flashcards as an en expert said (Adimayanti \& Siyamti, 2020). The form of the flashcard used is the one that has been standardized or the form of the work itself or in free form. The standardized form is a flashcard which can be purchased directly in bookstores. These young mothers can make flashcards from the most basic form to flashcards that have a front and back view of the card that can be used. How to use flashcards can vary from the simplest to combining games that are supposed to attract children's attention to learning.

The following is a role play for using flashcards by default where the card user must always be able to change the position of the card from front to back and vice versa. Here are some points to remember for presenting flash cards to be successful:

1. Pictures / words / numbers must be large and clear.

2. Images / words / numbers must have eye-catching colors

3. The presentation should be brief.

4. The card must be shaped or decorated as beautifully as possible, where the card or decoration allows it to be made by yourself. While the equipment used can use cardboard or by using used cardboard paper.

5. The card can be used alternately between mother and child in using the card, so that both parties can play an active role.

6. These cards can also be combined and matched with various games that can support the success of these cards.

7. the card is used as often as possible to make it easier to remember about the vocabulary on the card.

As already mentioned, there are two forms of flash cards, namely store-bought and self-made raw forms. Store bought flashcard can be bought easily in store, children and parent can choose it based on the purpose or the cost. 
Picture 1. Store bought flashcards

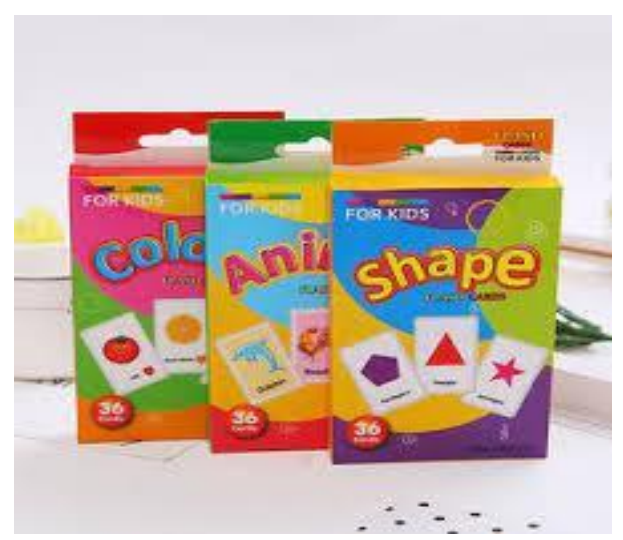

Self made raw form of flashcard is a flash card that was made by young mothers based on their creativities. The young mothers choses this kind of flashcard to use. The reason was cheap and free to make an expression and based on their need.

Picture2. Self made raw of flashcards

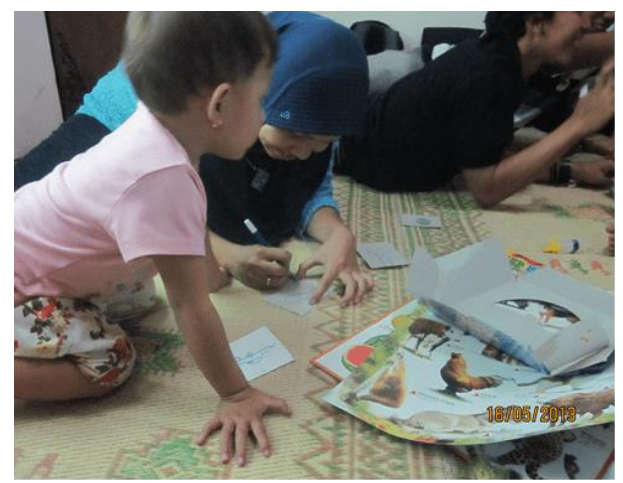

These young mothers prefer to use flashcards which comes from used goods such as milk boxes, food boxes, aqua boxes, or snack boxes. Furthermore, the cardboard is decorated by drawing it using a bolpein or marker and then coloring it yourself. If this is too much for the child, there is another way, namely by browsing pictures from the internet. Then the picture is attached to the recycled cardboard.

When young mothers use their flashcards, their children's interest in learning foreign languages is getting better. The reason is because these children do not realize that they are actually being invited to study with their mother. When learning takes place, children think that their mother is teaching a game combined with easy to understand songs. The interest of one of the children in learning can be seen in the picture below:

Picture 3. Children enthusiastic

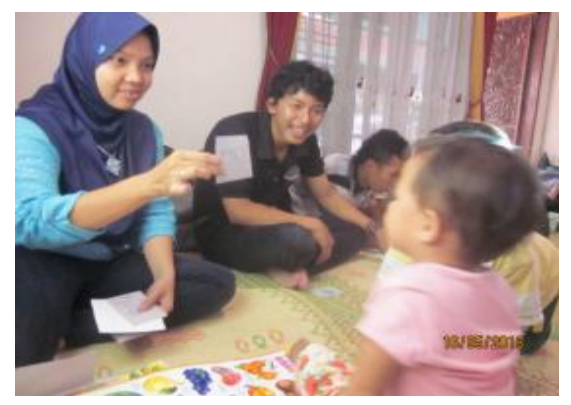

Surakarta English and Literature Journal 
There are several scenarios for the application of Flashcards by young mothers in Dawis PKK Desa Duabelasan Jombor Sukoharjo, as it can be seen in the table below:

Table 1. The flashcard application scenarios

\begin{tabular}{|c|c|c|c|}
\hline NO & Flashcard application & $\begin{array}{l}\text { Number } \\
\text { applied }\end{array}$ & young mother \\
\hline 1 & $\begin{array}{l}\text { Flashcards in the standard way, namely quickly changing } \\
\text { flashcards in front of the children, }\end{array}$ & & 7 \\
\hline 2 & flashcards combined with songs & & 5 \\
\hline \multirow[t]{2}{*}{3} & flashcards combined with hide and seek games & & 3 \\
\hline & Total & & 15 \\
\hline
\end{tabular}

Here it is the explanation the table above.

The first scenario is a standardized scenario. It usually do by people who learn language or mathematics through flashcard. The mother holds the flashcards of 5 cards first then the child sits in front of the mother. After that the mother will replace the card with a count of 5 seconds while saying the words written on the card. The reason for card replacement is a maximum of 5 seconds because it is to avoid the boredom of young learners in learning to use flashcards. Another reason, early childhood children feel bored very quickly. This can be observed when the observation is made. The young mother did not need to memorize the flashcard with the picture on it because the back of the card also had the same writing as the text that felt under the picture. The difference is that the writing on the back of the card is small. The consideration is quite legible by the young mother.

The flashcards used in teaching are accompanied by English songs that have existed in the school environment, such as the part of body song (Head shoulder knees and toes), the song is used in conjunction with flashcards that teach about part of body images. The songs used by these young mothers had previously been learned and memorized, which then became a provision for the young mother to teach English to children.

The song teaches the children to learn to pronounce and memorize English vocabulary in a relaxed manner. These children feel that they are not burdened when learning English so that the vocabulary absorption process is maximized when compared to just learning from books.

During learning with the help of flashcards and songs, they could unconsciously say parts of the body, animal names in English, and other basic English vocabulary. This is because children at the time of their study do not feel overwhelmed to learn so that these flashcards are very helpful for mastering English vocabulary.

The young mothers usually make a preparation before teaching the young learner because these young mothers understand that English is a second language which will create difficulties for young learners. At an early age these children are just learning to master Indonesian as the unified language in their schools, so that English as the language that comes after their mother tongue and unified language is not an obstacle for children to learn a foreign language, in this case is English.

The flashcards used can also be applied in conjunction with the game. The game used is a game of hide and seek. In this game, it is not the child who is hiding but the card. The card has two sides, namely a side with pictures and writing and the other side with writing. When the game is in progress, the cards are lined up with the visible position is the writing. Then the child is asked to find or find the correct writing from what the young mothers said.

Surakarta English and Literature Journal 


\section{Discussion}

\section{The use of Flash cards has advantages and disadvantages in teaching.}

Flashcards are a learning medium that can be used to teach in various fields of science as it can be seen at (Ardiyanti et al., 2018). One of them is in the field of teaching English, however, the application of flashcards by young mothers in teaching English vocabulary to their children definitely has advantages and disadvantages. This is obtained by examining the application of these flashcards.

\section{The use or application of Flashcards in teaching English vocabulary by young mothers of Dawis PKK Desa Duabelasan Jombor Sukoharjo}

The flashcards used in Duabelasan Jombor Sukoharjo Village have made children in the village more familiar with English. This can be seen from the ability to recognize basic English vocabulary words that are close to them in accordance with the vocabulary that is usually taught by their mother.

Learning vocabulary recognition using flashcards has created a new perception that learning a foreign language in this case is not difficult. This can be seen from the time it takes children in the area to memorize English vocabulary. This happens because basically children, especially children at an early age, are always curious about new things that are around them. In addition, early childhood, as mentioned in the literature review, they love to learn by playing or moving their limbs. Early childhood still find it difficult to stay in one place for a long time, so the appropriate learning model for early childhood is to give them the opportunity to move as a form of learning or a way to help them learn.

In addition, these children do not appear to be forced to learn the vocabulary. This can be seen from the joy shown by the children during the learning process using the flashcard.

a. The flash cards used in the Twelve have three types of applications. The first is the use of flashcards according to the standard flashcard rules used around the world. The second is a flashcard that is used while accompanied by a song and students can be asked to move as well or we can express it as a sing and dance. The third is a flashcard that is implemented using hide and seek games.

Based on these three applications, children prefer flashcards that are interspersed and combined with sing and dance. This makes students more cheerful in learning and really enjoys the game without feeling overwhelmed, even students often ask for additional time to learn English by using flashcards that are alternated and combined with sing and dance.

The advantages of Flashcard teaching media for children in Desa Duabelasan.

The adavantages of flashcard application can be concluded by observing the application of learning by young mothers in

a. Like a game

Young mothers use flashcards to teach English vocabulary to their children during home lessons. The use of flashcards which are used by stacking them into one flashcard which will be used as learning media and then replacing them in no more than 15 seconds, this makes young children like to be invited to play. The game in question which is in accordance with how to use flashcards is hide and seek.

This make the children or young learners happy to learn English because they don't feel overwhelmed. The effect of this is to make it is easier for children to memorize the new vocabulary they get from studying with their mother.

\section{Surakarta English and Literature Journal}


b. It can be combined with other learning media such as songs

This flashcard is very flexible in its use if you understand how to use it properly and it is not boring for students. This flashcard can be used with songs. Song in this case as an assessment. Learners learn and memorize vocabulary by using flashcards then to check whether the learner, in this case, is an early age child who is the child of these young mothers.

Although the song here serves as a media assessment for young learners but they do not feel burdened.The young learner still feels comfortable and stabs at the ongoing assessment. This can be seen from the joy of the child who does not let go of the smile on their face while occasionally laughing off when realizing his mistake when mentioning the vocabulary of the limbs in English.this will not happen if young learners feel pressured in learning.

At the time of learning english by using the flashcard, young mothers feel relaxed in teaching because their children in learning English does not take a long time in learning.A young learner is not uncommon to ask for more time in learning the English vocabulary.

c. The last advantage is close relationship between mother and children.

Learning English that mothers teach their children has an effect on the closeness of children and parents. This is because every time there is free time when the child does not play out of the house together with his neighbors, young mother will teach as well as play using the flashcards as a learning media.

d. The flashcards used in the dawis of Duabelasan villages had another advantage.

The advantage is to train the creativity of young mothers in the environment. While viewed from the young learners' point of view, the flashcard trains the young learner's fine motor skills to hold a pencil and scratch the pencil with firm strokes. This is done so that young learners can write well in school.

\section{The lackness of using of Flashcard teaching media for children}

The application of flashcards to teach English vocabulary has several drawbacks.

a. Teachers must be creative and must find ways to integrate with other media on an ongoing basis. This can still attract students to learn.

Not all teachers can be creative. This creativity is obtained from experience and a willingness to learn to develop abilities, and insights, it can be concluded that creative teachers are teachers who want to get out of the comfort zone because they dare to try new things armed with their abilities and insights. The opposite of being creative is laziness. Lazy teachers will not want to leave their comfort zone because they become overwhelmed to learn and do new things.

b. Children feel bored in learning English using flashcards if they are bored if the teacher, in this case their mother, does not always replace pictures with new vocabulary if young learners have memorized the old flashcards.

Flashcards purchased in stores have a fixed vocabulary amount or amount of vocabulary. If the child has memorized it or for certain words, it is not or difficult to memorize even though the text and images that are seen do not change, it will bring boredom.

c. This can be reduced or even eliminated by creating different pictures from recycled materials such as used cardboard and then writing and decorating the pictures to represent the words that have been written. How to decorate pictures can be by inviting your little one to draw and decorate or the young mother directly make a picture that attracts children's attention. Mothers

\section{Surakarta English and Literature Journal}


should always create interesting pictures or often look for interesting pictures either from books or magazines or from browsing the internet

The other word, images must always be updated according to children's learning needs. use of flashcards in addition to learning to read, these cards can be used to learn and deepen foreign languages in this case is English.

\section{CONCLUSION}

From this study it can be concluded that the use of flashcards to teach English can be done in three ways. Flashcards in the standard way, namely quickly changing flashcards in front of the children, then flashcards combined with songs and lastly flashcards combined with hide and seek games. There are two advantages of a flashcard, it is like a game and it can be combined with a sing a song. The children like to learn $\mathrm{n}$ to play Flashcards especially for sing and dance. The children have a great courage in practicing sing and dance than to play hide and seek.

Apart from that, there are two weakness of using the flashcard. Teachers must be creative and must find ways to integrate with other media on an ongoing basis. Children feel bored in learning English using flashcards. Both have the problem solving. Solving for the first and second weakness, the young mother should not be lazy and should encourage their selves to look for new picture $n$ new vocabularies.

\section{REFERENCES}

Adimayanti, E., \& Siyamti, D. (2020). TERAPI BERMAIN ENGLISH GAMES UNTUK MENINGKATKAN KEMAMPUAN KOGNITIF ANAK PRASEKOLAH. Jurnal Pengabdian Kesehatan. https://doi.org/10.31596/jpk.v3i2.84

Ardiyanti, A., Bandu, I., \& Usman, M. (2018). PEMBELAJARAN KOSAKATA BAHASA PRANCIS DENGAN MEDIA FLASHCARD (STUDI KASUS PADA MAHASISWA SASTRA PRANCIS). JURNAL ILMU BUDAYA. https://doi.org/10.34050/jib.v6i1.4327

Bowen, G. A. (2009). Document analysis as a qualitative research method. Qualitative Research Journal. https://doi.org/10.3316/QRJ0902027

Davidavičienè, V. (2018). Research Methodology: An Introduction. https://doi.org/10.1007/978-3319-74173-4_1

Flick, U. (2012). Designing Qualitative Research. In Designing Qualitative Research. https://doi.org/10.4135/9781849208826

Fridani, Lara; Dhieni, N. (2014). Hakikat Perkembangan Bahasa Anak. Metode Pengembangan Bahasa.

Hidayat, N., Sukmaningrum, R., Musarokah, S., \& Hawa, F. (2012). MEDIA GLENN DOMAN SEBAGAI PENGAJARAN MEMBACA DAN MEMPERKAYA ENGLISH VOCABULARY ANAK SECARA MANDIRI DI RUMAH. E-DIMAS. https://doi.org/10.26877/edimas.v3i1.253

Khan, S. N. (2014). Qualitative Research Method: Grounded Theory. International Journal of Business and Management. https://doi.org/10.5539/ijbm.v9n11p224

Miles, M. B., \& Hubberman, A. M. (2014). Qualitative data analisys. In CEUR Workshop Proceedings.

Surakarta English and Literature Journal 
Musyahidah, U., Sriwahyuni, S., \& Darwis, D. (2019). HUBUNGAN ANTARA BERMAIN MENGENAL WARNA DENGAN PERKEMBANGAN KOGNITIF ANAK DI TK FRATER BAKTI LUHUR MAKASSAR. Jurnal Ilmiah Kesehatan Diagnosis. https://doi.org/10.35892/jikd.v14i3.251

National Reading Panel. (2000). Teaching children to read: An evidence-based assessment of the scientific research literature on reading and its implications for reading instruction. NIH Publication No. 00-4769.

Papert, S. (1972). Teaching Children Thinking. Programmed Learning and Educational Technology. https://doi.org/10.1080/1355800720090503

Rahman, B., \& Haryanto, H. (2014). PENINGKATAN KETERAMPILAN MEMBACA PERMULAAN MELALUI MEDIA FLASHCARD PADA SISWA KELAS I SDN BAJAYAU TENGAH 2. Jurnal Prima Edukasia. https://doi.org/10.21831/jpe.v2i2.2650

Rini, H. L. S., Dewi. S, A. C., \& Munawar, M. M. (2019). PENGARUH METODE GLENN DOMAN TERHADAP KEMAMPUAN MEMBACA PERMULAAN PADAUSIA 5-6 TAHUN DI TK MARANATHA 01 SEMARANG. PAUDIA : JURNAL PENELITIAN DALAM BIDANG PENDIDIKAN ANAK USIA DINI. https://doi.org/10.26877/paudia.v7i2.3267

Sitompul, E. Y. (2013). Teaching Vocabulary Using Flashcard and Word List. Journal of English and Education.

Sutton, J., \& Austin, Z. (2015). Qualitative Research Data Collection. Canadian Journal. 